\title{
Conditions and outlooks of growing stone fruits
}

\author{
Szabó, Z., Soltész, M., Apáti, F. \& Nyéki, J. \\ Centre for Agricultural Sciences and Engineering, University of Debrecen 138 Böszörményi St., \\ 4032 Debrecen, Hungary
}

Key words: fruit growing, stone fruit, variety, training system, fruitquality

\section{Introduction}

The amount of fruit produced in the world increases steadily by 10 million tons per year. In 2007. it was 555 million tons. Under the temperate zone. the majority of fruit belong to the pomaceous group. (apple 66 million tons. pear 20.5 million tons). but the ratio of stone fruits is also significant: peach 17.4. plums 9.9. apricot 3.1. sweet cherry 2.1. sour cherry 1.2 million tons.

In Hungary. fruit production declined during the last 20 years. Between 2004 and 2008. yearly 800 thousand tons of stone fruits have been harvested: $9.9 \%$ peach. $7.7 \%$ plum. 7.0 sour cherry. $4.3 \%$ apricot and $1.2 \%$ sweet cherry.

During the last decennia. also the planted area as well as the level of the technology used declined. Poor planting sites. lack of up to date plantations and technological insufficiencies are responsible for the variable and low means of yields. The country's mean (3-6 t/ha) is about the $30-50 \%$ only of the yield in advanced countries. The best plantations are successful. but their yields ( $8-15 \mathrm{t} / \mathrm{ha}$ ) are still low compared with that of the foreign intense orchards (20-60 t/ha).

In Hungary. the Japanese plums. apricots and peaches grow on the northern border of their growing area. and the choice of planting sites is especially important condition of success or yield security. Each growing region with different ecology requires a special assortment of varieties. whereas for sweet and sour cherry as well as plum may thrive well on most regions of the country.

Fruit growing in Hungary needs badly improvement from very point of view. Increasing intensity of the cultivation is indispensable. The use of rootstocks as well as the utilisation of varieties requiring different moments of technology is to be developed. High intensity of marketing and extension service are also claimed. which may transform the producing structures. radically.

\section{International relations}

Production increases with the population and the higher living standards. In 2007. 33.7 million tons of stone fruits are grown in the world. $38 \%$ of it in coming from China. About one half of it means peach. Plums are represented by 10 million tons; the majority of it is Japanese plum (also due to China's participation). Statistics of the FAO registered 3-3.5 million tons of apricot. 2 of sweet cherry. 1.2 of sour cherry (Table 1).

Table 1. Volumes of store-fruits grown in 2007 (t)

\begin{tabular}{|l|r|r|r|c|}
\hline \multicolumn{1}{|c|}{ Species } & Worldwide & Europe & Hungary & $\begin{array}{c}\text { Participation } \\
\text { (\%) of the } \\
\text { Northern- } \\
\text { Great-Plain } \\
\text { region from } \\
\text { Hungarian } \\
\text { total in 2005 }\end{array}$ \\
\hline Sweet cherry & 2083110 & 548237 & 6572 & 6.7 \\
\hline Sour cherry & 1188313 & 786861 & 42571 & 26.8 \\
\hline Plum & 9925469 & 1309728 & 30772 & 16.8 \\
\hline Apricot & 3068925 & 602542 & 21734 & 8.1 \\
\hline Peach & 17439531 & 4190485 & 40820 & 4.8 \\
\hline Total & 33705348 & 7437853 & 142469 & - \\
\hline
\end{tabular}

Source: FAOSTAT, KSH

In the developed countries and continents. large volumes of fruits are consumed. however. the increment of production is relatively lagging (North America) or even declines (European Union). On the contrary. intense development is found in the developing countries. mainly in Asia (e.g. China). At the moment. one third of the volume is produced in Asian countries.

The most temperate zone fruits are produced on the northern hemisphere (Table 2). Some countries are covering their own consumption (USA, China) and their trade with foreign countries is relatively negligible. Countries with high rates of export (e.g. Italy, France, Spain, Greece) consume only a fraction of their produce.

In China, the increment of production is mainly observed in apple, and in stone fruits, peach and plum. In 2007, the worldwide volume of the last mentioned fruits was produced in China by 48.6 and $46 \%$, respectively. Sweet cherry production is also steeply increasing. Non official data indicate that China grows more than 1 million tons of 
Table 2. Main producers of stone-fruits and their rate in 2007 (\%)

\begin{tabular}{|c|c|c|c|c|c|c|c|c|c|}
\hline \multicolumn{2}{|l|}{ Sweet cherry } & \multicolumn{2}{|l|}{ Sour cherry } & \multicolumn{2}{|l|}{ Plum } & \multicolumn{2}{|c|}{ Apricot } & \multicolumn{2}{|c|}{ Peach } \\
\hline Turkey & 19.1 & Russian federation & 27.0 & China & 48.6 & Turkey & 18.2 & China & 46.0 \\
\hline USA & 14.9 & Turkey & 15.2 & Serbia & 6.9 & Iran & 9.1 & Italy & 9.9 \\
\hline Iran & 10.8 & Ukraine & 11.3 & USA & 6.8 & Uzbekistan & 7.8 & Spain & 6.36 \\
\hline Italy & 7.0 & USA & 10.7 & Romania & 3.58 & Italy & 6.9 & USA & 5.8 \\
\hline Russian federation & 4.8 & Poland & 9.1 & Chile & 3.0 & France & 4.1 & Greece & 4.5 \\
\hline Syria & 3.6 & Iran & 4.2 & France & 2.5 & Japan & 3.9 & Turkey & 3.1 \\
\hline Spain & 3.5 & Hungary & 3.6 & Turkey & 2.4 & Alger & 3.8 & Iran & 2.2 \\
\hline Ukraine & 3.3 & Byelorussia & 2.5 & Spain & 1.9 & Syria & 3.7 & Egypt & 2.1 \\
\hline Romania & 3.1 & Germany & 2.4 & Russian federation & 1.8 & Morocco & 3.4 & France & 2.1 \\
\hline Greece & 3.0 & Uzbekistan & 1.9 & Italy & 1.8 & Spain & 2.9 & Chile & 1.5 \\
\hline
\end{tabular}

Source: FAOSTAT

apricots, which means one quarter of the worldwide volume. All stone fruit species are grown in the USA on large acreage by intense technology. Outstanding volumes (except of sour cherry) are exported by Italy, Spain and France. Large and increasing volumes of stone fruits are produced also in Turkey and Iran.

Countries interested most in importation of stone fruits are less favourable for fruit production regarding the climatic conditions (e.g. Germany, United Kingdom). During the last decennia, fruit production of the temperate zone of the southern hemisphere increased substantially and their produce is bound to be exported to the north. The shift of seasons there favourites the marketing of fresh fruit grown in Australia, New Zealand, South Africa and Chile on the European markets.

The expanding of fruit offered stimulated the acclimatisation of fruit species in both, temperate and subtropical countries. Production of temperate zone fruit species in subtropical and tropical countries increases precipitously: Egypt, Morocco, Argentina, Brazil and Southern Korea are at the present significant peach growing countries.

After China and the USA, European countries are the most important producers of stone fruits. In Europe, 2007, $19.6 \%$ of apricot, $13.2 \%$ of plum, $24.0 \%$ of peach and $26.3 \%$ sweet cherry of the whole world are grown, whereas the majority of sour cherry (66.2\%) was produced in Europe.

\section{Tendencies in breeding of varieties}

During a period of 10 years (1995-2005), more than 1800 new stone fruit varieties have been registered. Most of them were peaches and nectarines (645 and 434), which are already grown. New sweet cherry, plum and apricot varieties are trespassing 200. New sour cherry varieties are listed as 34 ). There are new species hybrids as registered varieties: e.g. 37 plum $\times$ apricot hybrids.

About the half of new peach, nectarine and Japanese plum varieties is bred in the USA, but increasing numbers are coming from Ital and France. The number of varieties produced by private breeders is also increasing. That is also the reason that most of the new varieties are protected by law. After the apple clubs, we saw the appearance of stone fruit clubs (sweet cherry, apricot, peach). It was aimed generally to increase yield, extend the time of maturity, etc. but also new trends are observed:

- to reduce working requirement for training the trees, less pruning, (reduced vigour, column-like growth).

- resistance or tolerance to different diseases and pests,

- extension of the growing area beyond climatic boundaries,

- increasing the variability of fruit types,

- improved nutritional value of the fruit,

- better quality,

- better storability and prolonged shelf life.

\section{What is in Hungary}

During the last 20 years, the volume of our fruit production sunk to its half. The partitioning and neglect of the large-scale plantations caused a regression of yields. Apple is invariably the dominant fruit species with a ratio of $50-60 \%$, and stone fruits are represented by $30 \%$ (Table 3 ).

The yearly mean of the Hungarian fruit production is 800000 tons, $30 \%$ of it is stone fruit. Adverse ecological conditions, aging plantations, lack of intense technologies and obsolete varieties are blamed for the general

Table 3. Yields and trade of stone fruits (2007)

\begin{tabular}{|l|c|c|c|c|c|}
\hline \multicolumn{1}{|c|}{ Species } & $\begin{array}{c}\text { Plantation } \\
\text { (ha) }\end{array}$ & $\begin{array}{c}\text { Yield } \\
\text { (t) }\end{array}$ & $\begin{array}{c}\text { Purchased } \\
\text { for processing } \\
(\mathrm{t})\end{array}$ & $\begin{array}{c}\text { Export } \\
\text { (t) }\end{array}$ & $\begin{array}{c}\text { Import } \\
\text { (t) }\end{array}$ \\
\hline Sweet cherry & 1239 & 7500 & 1000 & 797 & 10 \\
\hline Sour cherry & 8766 & 49400 & 43400 & 10148 & 2727 \\
\hline Plum & 5540 & 47000 & 8300 & 6583 & 2419 \\
\hline Apricot & 4650 & 24000 & 2500 & 1218 & 449 \\
\hline Peach & 6236 & 48500 & 17700 & 191 & 12973 \\
\hline Total & 26431 & 176400 & 72900 & 18937 & 18579 \\
\hline
\end{tabular}

Source: Fruitveb 
backwardness, low and variable yields. In 2007, spring frosts reduced yields extremely on the eastern part of the country.

The total surface of orchards, 74376 ha, are divided into $50.8 \%$ apple, and $35.5 \%$ stone fruit plantations. Yearly differences in the rate of export and import of processed fruit (according to the actual yields) may become manifold. High rates of export are registered in sour cherry, but negligible in sweet cherry and peach. Outlooks of export are increasing in sweet cherry and apricot.

Rates of import are nearly equal with that of export. Large volumes of peach for fresh consumption are imported from Italy.

In the modern chain of international supermarkets require high quality and continuous supply, which is met with varieties producing high yields only. The competitiveness within the European Union is the most decisive condition of survival (Table 4). In the country, there are already new stone fruit plantations, where up to date, intense technologies are applied and the produce is delivered to the most exigent markets (Britain, Switzerland).

Table 4. Mean yields of stone fruits in Hungary and abroad (t/ha)

\begin{tabular}{|l|c|c|c|c|}
\hline \multicolumn{1}{|c|}{ Species } & $\begin{array}{c}\text { Mean yields } \\
\text { in Hungary } \\
\text { during } \\
\text { the last years }\end{array}$ & $\begin{array}{c}\text { Mean yields } \\
\text { of the best } \\
\text { plantations } \\
\text { in Hungary }\end{array}$ & $\begin{array}{c}\text { Mean yields } \\
\text { of the best } \\
\text { plantations } \\
\text { of the world }\end{array}$ & $\begin{array}{c}\text { Mean } \\
\text { potential } \\
\text { yields of high } \\
\text { quality } \\
\text { in Hungary }\end{array}$ \\
\hline Sweet cherry & $3-5$ & $8-10$ & $10-20$ & $10-20$ \\
\hline Sour cherry & $3-5$ & $15-20$ & $10-20$ & $25-20$ \\
\hline Plum & $5-6$ & $20-30$ & $30-40$ & $20-30$ \\
\hline Apricot & $3-4$ & $8-12$ & $15-30$ & $15-20$ \\
\hline Peach & $4-6$ & $15-20$ & $40-60$ & $15-40$ \\
\hline
\end{tabular}

(Source: Nyéki - Soltész - Szabó. 1997)

\section{Ecological conditions}

The Hungarian territory is coincident with the northern border of Japanese plum, apricot and peach as far as the growing is economically still feasible. North and west beyond Hungary, the risk of production is prohibitive and yields are too low.

In Mediterranean countries yields are higher and fruits attain larger size. The cover colour and aromatic substances are more favourable in Hungary.

The global changes of the climate are coupled with higher frequency of excesses. The yield, quantity and quality, are impaired at increasingly higher rates by minimum temperatures during the winter and spring, hails, long periods of droughts, strong winds. Some of the damages could be prevented or repaired by technical means, which are available and feasible in large-scale plantations.

Sour cherry and plum are successfully grown all over the country. Japanese plum, apricot and peach are preferably recommended to "protected" and well-drained slopes. It is a question of competitiveness to choose the adequate variety to the respective growing site. Regretfully, many plantations of stone fruits are on uncongenial sites. Almost every second year, winter- and sprig frosts reduce yields of peach at the Szatymaz region, and of apricots around the town Kecskemét. There we need frost-tolerant varieties and may apply technical defence procedures. Apricot growing was also transferred from the Great Plain to the northern region Gönc to the hillsides.

The damage caused by low temperatures is manifested on fruit varieties along a broad scale. The frequency and intensity of frost damages are demonstrated in Table 5 for the sake of comparison on several fruit species. As apricot and peach being susceptible to frost, orchards have been planted widely on the Great Plain. Those species are most referred to as susceptible examples.

Table 5. Frequency and maximum rates of losses of yield due to winter- and spring frosts in fruit plantations under Hungarian conditions

\begin{tabular}{|c|c|c|}
\hline Species & $\begin{array}{l}\text { Significant* damages } \\
\text { of yield are expected } \\
\text { at the frequencies } \\
\text { indicated (years) }\end{array}$ & $\begin{array}{c}\text { Maximum losses } \\
\text { on the countrywide } \\
\text { level }(\%)\end{array}$ \\
\hline Apple & $4-5$ & $20-30$ \\
\hline Pear & $4-5$ & 20 \\
\hline Sweet cherry & $8-10$ & 20 \\
\hline Sour cherry & $8-10$ & 10 \\
\hline European plum & $8-10$ & 10 \\
\hline Japanese plum & $2-3$ & $30-40$ \\
\hline Apricot & $2-3$ & 60 \\
\hline Peach & $2-3$ & $30-40$ \\
\hline Raspberry & $8-10$ & 10 \\
\hline Blackberry & $8-10$ & 10 \\
\hline Strawberry & $4-5$ & 10 \\
\hline Walnut & $4-5$ & 20 \\
\hline Almond & $2-3$ & 30 \\
\hline \multicolumn{3}{|l|}{ Source: Szabó. 2003} \\
\hline
\end{tabular}

Yields of European plums and sour cherries are generally exempt to winter and spring frost damages. However, there are some susceptible varieties, which may suffer heavily at low spots where the cold air accumulates. Apricot, peach and Japanese plum plantations on the Great Plain yielded copiously in 3-4 years out of 10 , another $3-4$ years produce mediocre yields, the rest of 3 years will become a failure.

There are several procedures serving for the prevention of frost damage in flowers. The most known is the air mixing technique. It was first of all used in apple plantations, but proved good also in peach. In French and Italian growers use paraffin stoves in the plantations and may avert frost as severe as $-8{ }^{\circ} \mathrm{C}$ (below zero). Experiences are similar in Hungary.

The higher frequency of hails could be met with net covers, where the expenses ought to be calculated for intense stone fruit plantations.

In the future, we have to upgrade in planning the role of the growing site. The recommendation of varieties must be 
applied to individual growing sites, also in Hungary. For that purpose, pilot plantations are suggested in each region, which may prove the preferences experimentally.

The small trees of intense plantations are relatively more susceptible than the trees of the traditional orchards, therefore the site should be carefully chosen.

It is generally accepted that sour cherry and European plum are stone fruits, which are safely grown in the NE region of the Great Plain.

\section{Use of varieties}

For the intensive plantations of high density, weakly growing (dwarfing type) rootstocks, and varieties are needed. All stone fruit species could find adequate dwarfing rootstocks, however, they are not introduced to Hungary yet.

The varieties of Hungarian origin are decisive in the assortment of sour cherry and apricot. In other stone fruit species, varieties of foreign origin prevail.

In Table 6 the varieties raised in the Hungarian nurseries between 1997 and 2003 are presented. During the cited period many thousand hectares plantation have been sponsored by state subvention. Those plants decided the variety profile of the subsequent years. The rate of investments declined after 2004 drastically.

Hungarian nurseries did not propagate foreign varieties with promising perspective, therefore many growers planted old, sometimes less marketable varieties until 2004.

The use of varieties has been conserved for a period. Some of them, seemingly promising varieties enjoyed popularity (e.g. a anska lepotica plum). Some temporary overproduction symptoms appeared during the last years.

Some growers of innovative spirit imported varieties, which corresponded with tendencies of the market.

In Table 6, the varieties used mainly in home gardens are also involved. Some of them are grown only in home gardens (e.g. 'Debreceni muskotály' plum, 'Champion' and 'Mariska' peaches).
In Sweet cherry, Hungarian hybrids, clones and local varieties are still significant. In the near future the appearance of new, self-fertile varieties with outstanding quality is expected. Those are eligible to be tested under Hungarian conditions.

The Hungarian sour cherry assortment is outstanding on a worldwide scale. Regionally selected clones and purposeful crosses resulted in high quality fruits mainly for fresh consumption.

The abundance of varieties does not appear in the practice of the growers. The half of the trees offered by the nurseries belong to the regional selections of NE-Hungary ('Újfehértói fürtös', 'Debreceni bőtermő', 'Kántorjánosi'), and one third of them 'Érdi bötermö'. The extension of the ripening period may justify a much broader assortment with varieties for processing and of similar quality as the mentioned ones.

During the years of 1970 and 1980, several early fruiting, large size and fertile European plum varieties have been introduced. The ripening periods lasted from early July until the second decade (mid) of September. Further foreign varieties are expected to contribute to the assortment without essential changes of the profile.

Growing of Japanese plums will increase, as expected, being experienced in countries of South Europe. Up to now, we proved that some varieties promise yields comparable with apricot and peach regarding the security of growing. The abundant and cheap import warns from further extension of the culture.

Apricot varieties occupy a relatively short ripening period, especially between early July and early August. Mainly Hungarian varieties are offered, but during the last 1-2 decennia varieties appeared abroad with claims suitable to Hugarian climatic conditions. They are favourably completing the ripening period and fruit quality. In Europe, the season of apricots is beginning with the end of April from Spain. The main apricot growing countries (Spain, France, Italy) finish the harvest until mid of July. After that, every quantity would be accepted in the markets of the EU.

Table 6. Rate of stone fruit varieties multiplied in the nurseries of Hungary 1997-200

\begin{tabular}{|c|c|c|c|c|c|c|c|c|c|}
\hline \multicolumn{2}{|l|}{ Sweet cherry } & \multicolumn{2}{|l|}{ Sour cherry } & \multicolumn{2}{|l|}{ Plum } & \multicolumn{2}{|c|}{ Apricot } & \multicolumn{2}{|l|}{ Peach } \\
\hline Turkey & 19.1 & Russian federation & 27.0 & China & 48.6 & Turkey & 18.2 & China & 46.0 \\
\hline Germersdorfi óriás & 29.3 & Érdi bőtermő & 33.3 & a anska lepotica & 35.1 & Magyar kajszi & 32.3 & Redhaven & 13.0 \\
\hline Bigarreau Burlat & 13.4 & Újfehértói fürtös & 23.8 & Stanley & 11.0 & Ceglédi óriás & 18.9 & Suncrest & 10.1 \\
\hline Katalin & 11.0 & Debreceni bőtermő & 19.7 & Bluefre & 8.4 & Bergeron & 13.2 & Champion & 8.3 \\
\hline Van & 10.7 & Kántorjánosi & 12.6 & Besztercei szilva & 8.3 & Pannonia & 7.8 & Flavortop & 6.9 \\
\hline Linda & 9.6 & 16 other varieties & 10.6 & President & 8.2 & Ceglédi bíbor & 5.0 & Early Redhaven & 5.9 \\
\hline Stella & 4.7 & & & Cacanska rana & 5.0 & Mandulakajszi & 3.1 & Dixired & 5.7 \\
\hline Margit & 4.6 & & & Althann ringló & 4.2 & Toyesi & 2.8 & Cresthaven & 5.1 \\
\hline Szomolyai fekete & 3.1 & & & Cacanska rodna & 3.9 & Ceglédi arany & 2.8 & Babygold sorozat & 4.4 \\
\hline Hédelfingeni óriás & 2.4 & & & Elena & 3.2 & Ceglédi Piroska & 2.4 & Mariska & 3.6 \\
\hline Valerij Cskalov & 1.6 & & & Debreceni muskotály & 2.4 & Ligeti óriás & 1.7 & Fantasia & 3.2 \\
\hline 30 other varieties & 9.1 & & & 22 other European p. & 8.2 & Budapest & 1.7 & Michelini & 2.7 \\
\hline & & & & 5 Japanese plums & 2.0 & 30 other varieties & 8.2 & 51 other varieties & 30.3 \\
\hline
\end{tabular}


In spite of the large number of varieties in peach and nectarine, the offer of fruits during the long ripening period is not continuous in excellent quality. Regarding the Hungarian demands and that of other advanced countries, the following groups are distinguished:

- nectarines,

- white flesh varieties,

- varieties of strong cover colour,

- less hairy peaches,

- varieties with slow after ripening,

- varieties with low acidity,

- varieties with flat fruit form,

The success of production depends largely on the speed of acceptance and spreading of new varieties. All stone fruit species expect the appearance of new varieties in each region. From this point of view, the sour cherry of the Nyirség region, sweet cherry of Eger-Szomolya and of Budakalász, plum of Szatmár, apricot of the region between Duna-Tisza, peach of the region Szeged-Szatymaz maintained their special fame.

Breeding of fruit varieties does not receive significant state subvention, therefore a decline of varieties originating from Hungary is expected. Foreign and international varieties will gain continuously also in sweet cherry and apricot assortments, moreover, foreign sour cherry varieties will appear.

\section{Training system}

Vase (funnel) and spindle crowns are recommended for dense plantations, where the distance between trees is smaller than in traditional orchards. The reduced vigour of the trees, due to the stocks, shortens the time until fruiting begins. On the small trees the ratio of high quality fruits increases, the harvest is much easier and keeps the quality of the fruits. Most favourable for quality is the $5 \times 3 \mathrm{~m}$ planting system of spindle crowns with central axis: best quality and uniformity is secured because optimum incidence of light.

The slender spindle has been applied for peach first in the world successfully. In the plantation, distance between the hedge-walls, i.e. rows is $1-1,5 \mathrm{~m}$. light is optimal, ripening ensues uniformly, harvesting can be concentrated therefore it's cheaper and easier. In Hungary, trees should not trespass 4-5 $\mathrm{m}$ height because the lower parts of the crown are in shadow and produce fruits of lower quality. Ecological conditions, however, may impair the maintenance of balance of fruiting along the long axis, compared with southern countries, where the risk of frost damage is lower.

Slender spindle crown is easy to train in sweet cherry among the stone fruits. In other stone fruit species, the use of slender spindle is limited by biological and economical reasons. For all species, it is a general truth that the high costs of investment prolong the period of returns at the existing prices. Among the biological limits we may mention the lack of suitable varieties (in sour cherry and apricot), the low yielding security at the respective sites (apricot, peach), low yields, high pruning requirements, which may increase the incidence of wilting branches and whole trees due to diseases.

Foreign experiences prove the feasibility of slender spindle also with apricot $(4.5-5 \times 1.2 \mathrm{~m}$ distance $)$, which produces considerable and high quality yields already in the second year after planting.

The uniform illumination of the crown is especially an imperative for peach and apricot. The extension of the cover colour on the fruit is an important criterion of marketability. Where the shadow covers the crown, the size of fruits is also reduced. The lager differences are between the light incidences within the crown, the lower is the uniformity of the fruit quality. The disadvantages show up in the reduced prices as well as the increased costs of harvest and of post harvest operations. Poorly illuminated parts of the crown develop less flower buds, and the heterogeneity within the tree is stimulated.

As a consequence of the facts presented above, we state that in stone fruits, the light supply of the branches requires also other solutions as the use of vase or funnel crowns, where the small-size-crowns cannot provide the right illumination for the whole tree. With open crown structures, shorter trunks than those required for mechanical harvest facilitate manual harvesting, and so effectiveness of manual harvest increases. At present in Hungary, the most utilised and recommended crown forms are summarised in Table 7.

Table 7. Training of the crowns and planting designs of stone fruit plantations recommended in Hungary

\begin{tabular}{|c|c|c|c|c|c|}
\hline \multirow[b]{2}{*}{ Species } & \multicolumn{2}{|c|}{ Used at present } & \multicolumn{2}{|c|}{ Recommended } & \multirow{2}{*}{$\begin{array}{c}\text { Maximum planting } \\
\text { density without } \\
\text { impairing fruit } \\
\text { quality (tree/ha) }\end{array}$} \\
\hline & Crown type & Planting design (m) & Crown type & Planting design (m) & \\
\hline Sweet cherry & vase combined & $7-8 \times 4-5$ & spindle vase & $4.5-5 \times 2.5-3$ & 8000 \\
\hline Sour cherry & vase combined & $7-8 \times 4-5$ & spindle vase & $5 \times 3$ & 1500 \\
\hline Plum & vase combined & $7-8 \times 4-5$ & spindle vase & $\begin{array}{l}6 \times 4 \\
5 \times 3 \\
\end{array}$ & 1500 \\
\hline Apricot & vase combined & $7-8 \times 4-5$ & vase & $5-6 \times 4$ & 1000 \\
\hline Peach & vase funnel shape & $6 \times 4$ & $\begin{array}{c}\text { vase, retarded vase } \\
\text { slender spindle }\end{array}$ & $\begin{array}{c}5-6 \times 4-3 \\
4.5-5 \times 1.5-2\end{array}$ & 2000 \\
\hline
\end{tabular}




\section{Fruit quality}

Quality means the ensemble of characters, which contribute to the suitability of a commodity, in this case of the fruit destined to be consumed as fresh fruit or processed.

Parameters of quality are a combination of properties of the variety plus the effects due to the growing site and to the procedures applied in its production. Emphasis deserves the sanitary state (health) of the fruit, which set a limit of the quality on the tree

- viruses, plant diseases, animal pests any traces or effects of their presence;

- deleterious chemicals (residues of phytosanitary sprays);

- deformations and discolorations on the surface or in the inner parts of the fruit due the physiological or pathological causes (e.g. browning, gummosis, etc.);

- mechanical lesions (sunburn, hail, friction of branches, etc.).

Requirements of fruit quality are changing with the habits of consumption. The channels of marketing, the distance of transport may influence the quality continuously. On the markets, the habits of consumption are determined by the rather conservative traditions. In Asia, the "giant" size, low acidity and perfect appearance are esteemed, whereas the extension and intensity of the cover colour less important.

In America and Western Europe, hard fruit consistency and transport -tolerant, intensely coloured and more acid fruits are preferred. In warm countries of the world, fruits are sweeter and the consumers also prefer the sweet fruits. The market value of the fruit depends also on the respective species at different degrees.

The quality developed in the fruit on the tree is influenced by the harvest operation and post harvest conditions at some degree, but the original quality cannot be improved substantially. On the contrary, wrong harvesting techniques and subsequent manipulations may spoil very easily the originally acceptable quality of the fruit. Good quality begins with the proper growing technology, which should be maintained and conserved through the adventures of harvest and subsequent treatments. The proper information of the consumers is an important component of keeping the quality of the fruit.

\section{The economy of stone fruit growing}

An inherent property of the fruit market of the main fruit species - as most stone fruits - is the overproduction in Hungary as well as on the markets of the European Union. Therefore, the producer's prices are almost every year low. The prices tend to diminish (their real value) on the home market as well as abroad during the last two decennia. There is no hope of increasing prices in the future neither. One of the causes is mainly the developing countries (China, Brasilia, Turkey, Iran, etc.) enjoy comparative advantages related to that of the growers of the EU because their costs of production are relatively low and the distances are overcome easily by modern logistic.

The abolition of customs influenced the chances of competition also in Hungary, as we must expose our produce to the offer of cheap imported goods. This relation is fully palpable with the cases of Italian peach and Polish sour cherry.

Those increasing tendencies, most likely, will not allow the raising of prices, on the contrary, the competition will become harder. The diminution of production costs is stimulated, which should be coupled with increasing efficacy. On the long run, the economy requires a continuous effort of lowering costs of production, increasing yields, meanwhile, raising or keeping the quality. At the same time, we have to consider the consequences of climatic changes, which took their toll with the weather excesses (e.g. the total frost damages of 2007 and hails in May-June of 2008). Every measure to avoid similar distresses will only increase the costs of production and investments. Serious questions emerge related to state subventions (planting and other investments), which will shortened around 2013, as anticipated.

The increasing competition, adverse changes of the climate, diminution of state subventions, all suggest that the costs of production cannot be diminished, on the contrary, substantial increments are justified (e.g. protection against rain and hail, installation of watering systems).

Let alone the aspects of the increasing competition, a further peculiarity of the fruit market (including stone fruits) is the highly uncertain variation of the production prices and of the highly dubious annual marketing security. The hectic changes of prices between seasons or even within the same season may attain more than $100 \%$. All those hit the reasonability of planning over longer terms. Unfortunately, the fate of a horticultural production branch might require a comprehensive survey at least for a life cycle of a plantation, which is really difficult to achieve.

The market of fruit never can be "completely" stable, the most we can do is the diminution of the uncertainty. The possible causes are:

- The regulation of the market is loose for the whole branch. Everybody may start producing. there are no legal restrictions, which may keep the capacities of production, consumption and trade within carefully planned boundaries.

- The rules and conditions of free trade are valid, nothing may prevent anybody to enter or quit the market.

- The processes of the market are regulated by the quantities of the offer and the demand and are realised in the prices. No institutional decisions exist regarding the prices. As the demand in on the national level relatively stable, the main factor determining the prices is the offered quantity of goods, which is highly dependent of the annual yield plus imported goods. 
- Production is delivered also to effects independent from the grower (e.g. weather), which causes ample variation in the quantity harvested annually, and cannot be planned beyond one year. The broad variation of the offer means difficulties in the harmonisation of offer and demand, which are almost unsurmountable.

In Hungary, the instability of the market, which causes the variation of prices not only in the short but also in the long run, it is aggravated by the vast conditions of commerce, and the lack of adequate information regarding trade and prices of the market.

As a conclusion, it is stated that the real production prices of stone fruits certainly will not rise significantly within 3-5 years, moreover, instability of prices will remain baffling.

Analysing the management of sour cherry and plum growing plants, we are convinced of the validity of statements that competitiveness of enterprises will not be sufficient unless the high yields and quality have achieved and at the same time the costs of production reduced to an acceptable level. Herewith, we show a real example.

Sour cherry grown for industrial processing cannot be produced cheaper than $120-150 \mathrm{Ft} / \mathrm{kg}$, with manual harvesting in up to date plantations yielding 10-12 t/ha as a mean. The actual producer's prices $50-100 \mathrm{Ft} / \mathrm{kg}$ are too low. If the price is $90-100 \mathrm{Ft} / \mathrm{kg}$, yields should be higher than 15-20 t/ha, which are impossible to achieve. It is obvious that prices will not rise significantly (reasonably), consequently the costs of production ought to be reduced in order to save the existence of the branch by means of technological development.

The industrial plum production is sold at the present prices $(10-40 \mathrm{Ft} / \mathrm{kg}$ ), which means that its return is near zero or negative. Acceptable economy supposes producer's prices of 50-60 Ft $/ \mathrm{kg}$, which postulates yields of 20-25 t/ha as a mean. Lower prices or lower yields condemn the plant to insolvency. However, the time of maturity of different varieties is a susceptible criterion of consumer's prices, whereas the costs of productions are nearly equal. The early and mid-season plums attain the lowest prices, whereas very early and late, moreover, very late ripening plums could earn considerable incomes. Nota bene, economy is not bound to terms of maturity in spite of the correlation. Adequate prices may justify varieties of any terms of maturity. The truth mentioned at the sour cherry, is valid for plum too: High yields alone do not help unless the costs of production are not reduced.

The two examples presented, sour cherry and plum, anticipate the necessity of mechanical harvesting at least for fruits grown for industrial processing. At the moment it seems the only reasonable way of reducing the costs of production. For this purpose, the plantation should be prepared just from the moment of planting according to the respective design. The switch from the traditional (manually harvested) plant to the mechanically harvested one is not a simple step. Shaking machines may find some possibility of use in traditional plantations, but for the full effectiveness we need considering some conditions:

- for mechanical harvest, the fruit should be detached from the stem (peduncle) without being wounded (i.e. dry), the flesh is hard as a property of the variety,

- the plantation should be large enough (several times ten hectares) to justify the investment and maintenance of the shaker,

- the assortment of the plantation must consist of varieties of different ripening terms from the earliest until the latest ripening, and the ratio of individual varieties should facilitate the continuous use of the shaker,

- the length of the trunk, specially trained crown, adequate planting design and cultivation system.

Summarising the suggestions, we anticipate that on the market of stone fruits, competitive farms will be maintained, with larger (several times 10 ha) plantations, equipped with mechanical harvesters (except for fruits of fresh consumption) and high yields (sour cherry: 15-20 t/ha, plum: 25-30 t/ha, sweet cherry: 10-15 t/ha, apricot: 15-20 t/ha, peach: 20-25 t/ha), high technologies, investments and professional erudition. Small farms (of less than 1-2 ha surface) and home gardens will prosper only under "severe" pressure of competition at the conditions of strict organisation (TÉSZ).

\section{Possibilities and agenda for the development of stone fruit production}

Before the details of development are elaborated, we have to analyse the entire branch and pick out the most important moments.

Competitiveness of stone fruit production will achieved by the realisation of a strictly coordinated study, which concentrates on the following points:

- For stone fruit plantations, the possibly optimum of growing sites ought to be chosen considering ecological conditions, growing traditions, existing capacities, which could be brought up to a modern level, possibilities of development as well as of aiming horizontal integrations. - At the sites chosen, organisations of production should be established or the existing ones continued. The possibilities of the market should be explored, the demands, capacities of logistic and employees registered, coordination of horizontally available acquaintances, organisation of cooperatives for the sake of security in production and marketing.

- The study of Hungarian and internationally available varieties of the respective stone fruit species from the point of view of their chances on the markets. Organising of raising planting material in nurseries for the planned planting season. 
- Introduction of technologies of increasing productivity, and yielding security in the growing practice of stone fruits. Elaboration and planning the prevention and repair of damages caused by threatening weather excesses and application of special technological means.

- Fruit grown for processing is cheaper, therefore the introduction of mechanical harvest is absolutely necessary in order to reduce costs of production.

- For the purpose of increasing fruit consumption, the nutritive and sanitary role of stone fruit consumption should be emphasised in professional papers and advertisements.

- Introduction of environmentally safe and energysparing technologies in stone-fruit growing practices.

- Conservation and breeding of Hungarian stone-fruit varieties, their adaptation and promotion of the acclimatisation of new foreign varieties including successful protected ones.

- Harmonisation of ripening periods of the assortment available for the purpose to distribute the marketing season and the capacity of technical as well as manual labour purposefully regarding the conditions of competition.

- Widening the scope of commodities developed from processed stone fruits (deep freezing, brandy, juice, dehydrated powder, etc.), which should improve the competitiveness as well as the chances of employment in the respective productive branch.

The Debrecen University (AMTC), Institute of Research and Development (KFI) is leading the $\mathrm{R}+\mathrm{D}$ activities and innovations in Hungarian fruit growing. Its main tasks are the search for new varieties and growing technologies and their introduction. The cooperation with many Hungarian as well as foreign universities, research stations and innovative enterprises is promoted by the system of competition of the NKTH consortium.

On twenty sites of different ecological conditions, pilot plants are managed, where the production of stone fruit varieties and technologies are tested regarding their performance and marketing potentialities.

Results of the research fellows of the $\mathrm{R}+\mathrm{D}$ institute are extended by the service to plantations of enterprises over thousands of hectares countrywide. 